

\title{
Dolichopithecus balcanicus sp. nov., a new Colobinae (Primates, Cercopithecidae) from the early Pliocene of southeastern Europe, with a discussion on the taxonomy of the genus
}

Nikolaï Spassov, Denis Geraads

\section{To cite this version:}

Nikolaï Spassov, Denis Geraads. Dolichopithecus balcanicus sp. nov., a new Colobinae (Primates, Cercopithecidae) from the early Pliocene of southeastern Europe, with a discussion on the taxonomy of the genus. Journal of Human Evolution, 2007, 52, pp.434-442. halshs-00157610

\author{
HAL Id: halshs-00157610 \\ https://shs.hal.science/halshs-00157610
}

Submitted on 26 Jun 2007

HAL is a multi-disciplinary open access archive for the deposit and dissemination of scientific research documents, whether they are published or not. The documents may come from teaching and research institutions in France or abroad, or from public or private research centers.
L'archive ouverte pluridisciplinaire HAL, est destinée au dépôt et à la diffusion de documents scientifiques de niveau recherche, publiés ou non, émanant des établissements d'enseignement et de recherche français ou étrangers, des laboratoires publics ou privés. 
Dolichopithecus balcanicus sp. nov., a new Colobinae (Primates, Cercopithecidae) from the Early Pliocene of South-eastern Europe, with a discussion on the taxonomy of the genus

Nikolai SPASSOV*, Denis GERAADS**

* National Museum of Natural History, Bulgarian Academy of Sciences, 1-Tzar Osvoboditel

Blvd., 1000 Sofia, Bulgaria; nspassov@nmnh.bas.bg

** UPR 2147 CNRS, 44 rue de l'Amiral Mouchez, F-75014 Paris (France);

dgeraads@ivry.cnrs.fr

KEY WORDS - Dolichopithecus balcanicus sp. nov., Cercopithecidae, Pliocene, Europe, Bulgaria

Running title: new Dolichopithecus from Bulgaria 
ABSTRACT - We describe here a new species of Dolichopithecus, D. balcanicus n. sp., from the Pliocene (late Ruscinian) of the Balkans. Although known by mandibular remains only, it is readily distinguished from the common European species, D. ruscinensis, by its smaller size, much shallower mandibular corpus, and crowding of the premolars. Ukrainian finds of "Adelopithecus" can be accommodated into D. ruscinensis, as a separate, smaller subspecies, D. ruscinensis hypsilophus, but the specimens reported from Asia are more distant, and they probably represent a separate subgenus of Dolichopithecus, the valid name of which is D. (Parapresbytis) Kalmykov \& Mashchenko.

\section{Introduction}

Dolichopithecus is a Pliocene colobine monkey well known from several sites in Europe, although closely related monkeys from the middle to late Pliocene of Japan, Siberia and Mongolia were recently included (the latter ones tentatively) in the genus (Delson, 1994; Iwamoto et al., 2005). Dolichopithecus has been reported from 16 localities from Spain and France to Ukraine. The latest revisions led to the conclusion that Dolichopithecus is represented in Europe by the single species D. ruscinensis (Depéret, 1889) without significant differences in size or morphology across geography and time (Delson, 1994; Delson et al., 2000, 2005). The biochronological range of the taxon extends from the Early Ruscinian (Montpellier, France and Beresti, Romania) to the Early Villafranchian (Balaruc-2, France: MNQ 16 and Baraolt-Capeni: the latter locality belongs to MNQ 16 according to Fejfar et al., 1997 or to the second half of the MNQ 15 according to Radulescu et al., 2003, as cited in Delson et al., 2005). New material from Bulgaria described here documents a new species of Dolichopithecus from southeastern Europe, and leads us to revise the taxonomy of the genus. 


\section{Abbreviations}

Specimens of Dolichopithecus ruscinensis are labelled FSL for those housed in Université Claude Bernard (formerly Faculté des Sciences), Lyon; Pp for those housed in Centre de Conservation et d'Etude des Collections, Lyon (CCECL, formerly housed in Musée Guimet d'Histoire Naturelle); Per for those housed in Muséum National d'Histoire Naturelle, Paris (MNHN). Other abbreviations: NMNHS: National Museum of Natural History-Sofia; LGPUT: Laboratory of Geology and Paleontology, University of Thessaloniki; MRAC: Musée Royal de l'Afrique Centrale, Tervuren.

\section{Systematics}

Order Primates Linnaeus, 1758

Hyporder Anthropoidea Mivart, 1864

Infraorder Catarrhini E. Geoffroy Saint-Hilaire, 1812

Parvorder Eucatarrhini Delson, 1977

Superfamily Cercopithecoidea Gray, 1821

Family Cercopithecidae Gray, 1821

Subfamily Colobinae Blyth, 1863 (1825)

Dolichopithecus Depéret, 1889

Type-species 
Dolichopithecus ruscinensis Depéret, 1889

Dolichopithecus balcanicus sp. nov.

Holotype (Fig. 2, A-D)

Right male mandibular corpus lacking symphyseal part and with damaged inferior border, bearing $\mathrm{m} 1-\mathrm{m} 3$ ( $\mathrm{m} 3$ lingually broken) and alveoli for c-p4*. No FM-1739 of the coll. of the NMNHS.

Type Locality

Tenevo, Bulgaria, MNQ 15?

Etymology

From the name of the Balkan peninsula where the remains of the new species were found (Fig. 1).

Referred material

Left mandibular corpus and fragment of a right mandibular corpus of a single female individual with right p3-m3 and left c1-m3 [described by Koufos et al., 1991 (No. MEV-1, LGPUT)]. Locality: Megalo Emvolon, MNQ 15, Greece.

Age of the localities

* lowercase denotes lower teeth, uppercase denotes upper teeth. 
Tenevo: The holotype mandible FM-1739 was found in the Tenevo (Malomir) sand quarry near the Tundja river bank, about $20 \mathrm{~km}$ south of the town of Yambol, in southeastern Bulgaria (Fig. 2, A-D). The alternating clays and sands of the quarry belong to the alluvial deposits of the Elhovska Formation (Kojumdjieva et al., 1984). Several other fossils were collected from this quarry in the 1980s by Georgi Ribarov. The fossils are currently in the collections of the National Museum of Natural History in Sofia, but remain unpublished. Besides Dolichopithecus balcanicus n. sp., the preliminary faunal list of the locality is as follows: Agriotherium insigne, Anancus arvernensis, Stephanorhinus cf. megarhinus, Hipparion sp., cf. Procapreolus sp., Paracamelus sp., cf. Parabos athanasiui, and Chelonia indet. cf. Cheirogaster sp. Agriotherium, Anancus arvernensis and Procapreolus have a long time-range in Europe, roughly from the early to the middle and late Pliocene. Stephanorhinus megarhinus is typical of the Ruscinian. Bovid metapodials different from those of the Early Ruscinian Parabos cordieri and the late Ruscinian P. macedoniae are referred tentatively to $P$. athanasiui, a poorly known Romanian form (Samson et al., 1971; Radulescu, 2005) which is typical for MNQ 15, and probably reached MNQ 16, but is not definitely known from MNQ 14. Paracamelus, besides a single late Miocene record in Spain, is mostly known in Europe from the early Villafranchian of Eastern Europe; it is already present in Romania in the late Ruscinian, but not as early as MNQ 14. Thus, as a whole the faunal association of Tenevo indicates a late Ruscinian age (MNQ 15).

Megalo Emvolon: It is located in the Chalkidiki Peninsula of Aegean Macedonia, northern Greece (Fig. 1). The faunal association of Megalo Emvolon was discussed by Koufos et al. (1991), who assigned it to MNQ 15. Therefore, Dolichopithecus balcanicus sp. nov. is restricted to the Late Ruscinian of the Balkan Peninsula. 


\section{Diagnosis}

Molars typical for the genus with very high lophids, extremely deep lingual notches and $\mathrm{m} 3$ with long hypoconulid which is shifted buccally and almost in line with the buccal cusps and without true tuberculum sextum. Size smaller than in the type-species. Corpus mandibulae smaller, narrower and shallower. Very short and crowded lower p4-c1 row, with teeth overlapping in lateral view (canine alveolus separated by a thin septum from the posterior root of p3 in males). Mandibular corpus markedly twisted (below the premolars, the lateral side faces somewhat ventrally), premolar row curving anteromedially and not in line with that of the molars.

\section{Description of the holotype (Fig. 2)}

Mandible: The mandibular body is preserved from the posterior part of the symphysis to distal $\mathrm{m} 3$. It is twisted along its anteroposterior axis, so that the anterior part is not vertical, but slanting medioventrally. The inferior border is eroded and slightly gnawed by rodents, but no spongiosa emerges under $\mathrm{m} 2$, and the amount of missing bone at this position can be estimated at $2 \mathrm{~mm}$ at most. The corpus is shallow, of uniform depth below the cheek teeth, and its premolar portion is short. A well expressed protuberance on the lateral surface below the roots of $\mathrm{m} 3$ marks the beginning of the linea obliqua. The alveolar row of the molars is not in line with that of the ante-molar teeth, as the latter are arranged in a curve oriented proximomedially. The mesial part of the canine alveolus is destroyed but its distal surface is preserved, showing that the alveolus is very deep, as in other male cercopithecids (including Dolichopithecus), almost reaching the inferior border of the corpus. Of the alveoli for the roots of $\mathrm{p} 3$, only the distal one is 
fully preserved. Remarkably, it is separated from that of the canine by a thin septum, not more than $2 \mathrm{~mm}$ thick. Most of the mesial alveolus is missing; only its distolingual part remains, as a narrow groove which is labial, but only slightly distal, to the canine alveolus, and separated from it by a thin septum. Its position shows that the axis of $\mathrm{p} 3$ was quite oblique in respect to the main axis of the tooth row, so that it much overlaps the canine in lateral view. The ventral contour of the mesial alveolus of $\mathrm{p} 4$ suggests that the mesio-buccal region of the crown was expanded inferiorly below the level of the molars, more suggestive of the Colobinae (especially males) than of the Cercopithecinae.

Teeth: The tooth crowns display typical colobine features (Szalay \& Delson, 1979) with high cristodont lophids, deep intervening basins, very deep lingual notches and a short trigonid basin. The base of the $\mathrm{m} 1$ metaconid is broken and the lingual surface of the $\mathrm{m} 3$ lophids is damaged, so that the anterior width of $\mathrm{m} 1$ and the widths of $\mathrm{m} 3$ cannot be precisely measured. The occlusal surface of the molar row is twisted in a sigmoid curve, so that $\mathrm{m} 3$ is inclined lingually in relation to the other molars although its inclination may be slightly accentuated by postmortem displacement. The $\mathrm{m} 3$ has the characteristics of a Dolichopithecus tooth: very high lophids, extremely deep lingual notches, and a long hypoconulid that is shifted buccally to lie almost in line with the buccal cusps. There is no true tuberculum sextum, as usual in the genus (Delson, 1973).

\section{Comparison of the holotype and discussion}

The molar morphology of the Tenevo mandible is typical for the Colobinae and it is compared here with the late Neogene representatives of this subfamily. 
Libypithecus Stromer, 1913. This genus was described on the basis of a single skull and referred isolated lower molar from the early Pliocene of Wadi Natrun (Egypt). A colobine of similar dental size and some postcranial elements from the late Miocene of Sahabi, Libya, may represent the same taxon (Szalay \& Delson, 1979; Delson, 1994). Morphological comparison with the Tenevo specimen is impossible because of the lack of homologous elements. However, Libypithecus is a long-faced monkey, whereas even though the length of the muzzle is not directly known at Tenevo, the rostral part of the mandible is so shortened that a long muzzle can most probably be ruled out.

Mesopithecus Wagner, 1839. Mesopithecus is the best-known late Miocene colobine of western Eurasia, being widespread from Germany to Afghanistan, with the best samples coming from Pikermi in Greece and Hadjidimovo in Bulgaria (Koufos et al., 2003 and references therein). The Tenevo mandible is closer in overall dimensions to a large Mesopithecus than to a male Dolichopithecus (Table 1), and several mandibular dimensions (such as mandible depth under the molars or mandibular corpus length) are comparable to the maximum Mesopithecus values. The molar row length is only a little larger than the largest Mesopithecus. On the other hand, the molar morphology, especially that of $\mathrm{m} 3$, is different from that of Mesopithecus, with higher cusps and deeper basins between the lophids and with a longer and buccally displaced hypoconulid, which is almost in line with the buccal cusps.

Parapresbytis eohanuman (Borissoglebskaya, 1981). The species Presbytis eohanuman was erected by Borissoglebskaya (1981) for two mandibles (both female, in our opinion) and some postcranial remains from the Early Villafranchian locality of Shamar in Mongolia. Kalmykov 
and Mashchenko (1992) created the genus Parapresbytis for it, on the basis of new upper jaw and cranial material from the Early Villafranchian of Udunga (Transbaikalian region, Siberia), a locality close to Shamar (see also Mashchenko, 2005). The taxonomic status of the genus and its diagnosis are debatable, given the fragmentary condition of the material. Indeed the differences between "Parapresbytis" eohanuman and Dolichopithecus noted by Borissoglebskaya (1981), relating to the presence of a mandibular corpus fossa and a less oblique and less developed mesiobuccal part of $\mathrm{p} 4$, are not reliable. The latter feature is sex-related: both specimens from Shamar display female features and a 4 morphology close to that of female D. ruscinensis (see discussion on sexual dimorphism below). A mandibular corpus fossa below p3-p4 is also present in D. ruscinensis, where it is not deep, but similar to that of the Shamar mandibles. The mandibular and dental dimensions of the latter are larger than those of the Tenevo specimens, and comparable (as are all Asian finds) to those of D. ruscinensis. However, in relation to the Tenevo material, it is interesting to note the shortness of the rostral part of the Udunga maxilla (Mashchenko, 2005) but the Shamar mandibles, the only fossil material from Asia that can be compared with the Tenevo mandible, do not have crowded lower premolars and canines. Furthermore, on one specimen at least (PIN-3381-236; cast kindly made available to us by G.D. Koufos), the m3 morphology greatly differs from that of Dolichopithecus sensu stricto, including the Tenevo mandible, by the low molar cusps and the large, transversely expanded $\mathrm{m} 3$ hypoconulid. Thus, the Shamar and Udunga material can be separated from the typical (European) Dolichopithecus.

Delson (1994) tentatively referred a male skull (without mandible) from the Early-Middle Villafranchian locality of Nakatsu, Japan, to Dolichopithecus eohanuman, thus in the same species as the Udunga and Shamar material. A similar position was held by Iwamoto et al. 
(2005), who proposed new subgeneric and specific names for the Japanese skull, Dolichopithecus (Kanagawapithecus) leptopostorbitalis. However, the strong differences in length of the facial part of the male skulls illustrated by Iwamoto et al. (2005) could in fact be artificial. The single skull of $D$. ruscinensis referred to a male is Per-002 from Perpignan, but its very elongated muzzle probably results from the strong crushing and vertical compression of the skull roof and rostral part. Even its sex is doubtful, as the only relatively intact upper canine alveolus is rather small, and the restored lengths of the tooth row and of the palate are hardly larger than those of the female skull Per-001, which has almost the same palatal width

It seems (contra Iwamoto et al., 2005), from the much damaged cranial finds from Udunga (Mashchenko, 2005), that the supraorbital ridge and the cranial roof of "Parapresbytis" eohanuman were quite similar to those of the Japanese species. It is difficult to evaluate the specific differences between "P." eohanuman from Mongolia and Russia (Buryatia) and D. leptopostorbitalis from Japan, but they are probably very close. They differ from the earlier European Dolichopithecus clade in tooth morphology (see the Shamar mandible) and perhaps in skull roof shape, and could represent a younger, eastern form of Dolichopithecus that can be distinguished as a separate subgenus, the valid name of which is D. (Parapresbytis) Kalmykov \& Mashchenko, 1992.

\section{Comparison with Dolichopithecus sensu stricto}

As in the Cercopithecidae in general, sexual dimorphism in Dolichopithecus is well expressed in size and morphology of the postcranial elements, of the canine-p3 complex, and apparently in the skull of $D$. ruscinensis (Szalay \& Delson, 1979). Thus, although sex determination of partial fossils of Dolichopithecus is not always easy, correct sex identifications 
of mandibular specimens of Dolichopithecus is important for the taxonomic interpretations proposed here. To evaluate intra-specific variation and sexual dimorphism in colobine mandibles, we measured a large sample ( 77 adult specimens) of two subspecies of modern Piliocolobus badius (P. b. badius and P. b. elliotti) in the MRAC, Tervuren. We also compared the large sample of mandibles from the type-locality of $D$. ruscinensis, Perpignan (MNQ 15a), the well-preserved mandibles from Megalo Emvolon (Greece), and casts of those from the Kuchurgan river valley, Ukraine (Mashchenko, 1991). We have not tried to examine the small samples from Baraolt-Capeni, Malusteni, Beresti and Ciuperceni-2, Romania and Ptolemais, Greece, because they include no adult mandible (Delson, 1973; Szalay \& Delson, 1979; Delson et al. 2004).

Perpignan: The p4s of some males (FSL-40906 and Per-003) have an obliquely expanded mesiobuccal region of the tooth crown, reminiscent of the $\mathrm{p} 3$ morphology, but others are more molariform (FSL-40183; Pp-3; Pp-10). The female p4s may also display this latter condition (Per-004, of which we have seen only a cast; Pp-3; FSL-40184), but some of them present the same morphology as the males (FSL-41288, which was given a male appearance by the addition of a felid canine, but which is definitely female by the shape of its $\mathrm{p} 3$ ).

The p3s of males are always larger than those of females, with an expanded mesiobuccal region of the tooth crown reaching well below the level of the molar cervix, as typical for male Cercopithecidae. In the females, the mesiobuccal part of the crown is normally not expanded (Per-004; FSL-40184; FSL-41288), but in some cases (Pp-3; Pp-29) it may become similar to those of males, and reach somewhat below the level of the molars, although not to the extent seen in males. 
These observations indicate that some females could have a shape of $\mathrm{p} 3$ and especially of p4 similar to those of males, but without the extreme development of the mesiobuccal region of p3. However, the female canine is always much smaller (FSL-40184; FSL-49995; Pp-29; Per004). The large canine alveolus in the Tenevo mandible, only slightly smaller than the root of the large male canine of D. ruscinensis from Dorkovo, DKV-79 (Delson et al., 2005), indicates that it is from a male individual.

The molar morphology of the Tenevo specimen is identical to that of D. ruscinensis from Perpignan, which has yielded the largest collection known to-date: very high lophids and extremely deep lingual notches, $\mathrm{m} 3$ with long, labially displaced hypoconulid. However, the Tenevo mandible differs in size and proportions from those of $D$. ruscinensis. It is the smallest specimen in individual molar size and molar row length of all known Dolichopithecus (Table 1; Fig. 3). Metric differences between the Tenevo specimen and the Perpignan males are conspicuously larger than those observed within the sample of male P. badius (Figs. 3-4). Two more features distinguish the Tenevo mandible from D. ruscinensis: 1) the mandibular corpus is much shallower, the depth being well below the minimum for the Perpignan sample (Fig. 4); 2) the canine and lower premolars are crowded. There is a tendency for the $\mathrm{p} 3$ of D. ruscinensis to take an oblique position in the tooth row, so that the anterior root becomes labially displaced relative to the main alveolar line. This is well expressed in specimens Per-003 and especially Pp2, a male right mandibular ramus in which the mesial p3 alveolus is labial to, and only slightly more distal than, that of the canine. This brings the latter close to the distal alveolus of $\mathrm{p} 3$, but they remain separated by a much thicker bone septum than in the Tenevo specimen. In modern Piliocolobus badius, crowding of the premolars is clearly a juvenile feature. The rostral part of the mandible lengthens when $\mathrm{m} 3$ erupts into occlusion, and the canine becomes more widely 
separated from $\mathrm{p} 4$. By contrast, the Tenevo mandible, which is fully adult, retains the juvenile condition.

Kuchurgan: Gremjatsky (1958) described Adelopithecus hypsilophus on three mandibular fragments from Grossulovo and Voynichevo in the Kuchurgan river valley (South Ukraine), without selecting a holotype. Later, Alekseeva (1964) described as Dolichopithecus $\mathrm{cf}$. ruscinensis a juvenile mandibular fragment from Novopetrovka, also in the Kuchurgan river valley. Szalay \& Delson (1979) tentatively synonymized Adelopithecus hypsilophus with Dolichopithecus ruscinensis, and the same opinion was held by Delson et al. (2005) after E. Delson had examined the Novopetrovka and other Ukrainian finds housed in the Kiev Museum (formerly the Zoological Institute), but not the original Gremjatsky specimens. In the meantime, Mashchenko $(1991,2005)$ had assessed the systematic position of Adelopithecus hypsilophus, and also regarded the generic name as a junior synonym of Dolichopithecus. He accepted the Novopetrovka material and an additional molar from Kotlovina in Ukraine as D. ruscinensis but continued to recognize the Voynichevo-Grossulovo material as a separate species, D. hypsilophus Gremjatsky. He re-described in detail two of the original specimens of D. hypsilophus, but not the specimen PIN-355-8, which he thought to be lost (E. Mashchenko, in lit., kindly informed us that it might still be in the collection of the Kiev Museum). Unfortunately, he (Mashchenko, 1991, p. 63) also called the latter the "holotype"; however, since he did not specifically mention that he chose this specimen as a lectotype, this designation is not valid (ICZN, art.74.5). We hereby select specimen PIN-355-7, the teeth of which are less worn (Gremjatsky, 1958; Mashchenko, 1991, fig. 2A) as lectotype. Its precise provenance was not mentioned by any author. Mashchenko $(1991,2005)$ notes some diagnostic differences of the Voynichevo-Grossulovo species: smaller mandibular corpus, flattened symphysis, smaller canine 
of the male specimen and very small incisors, plus some differences in the depth of the molar basins. Our examination of the casts (kindly sent to us by E. Mashchenko) of both available mandibles leads us to the following conclusions:

The dental and mandible morphology of the preserved regions of the fragments are not significantly different from those of the sample from the type locality of D. ruscinensis (Perpignan). The mandibles are indeed smaller but the significance of size must be evaluated in relation to the sex of the individuals. In Mashchenko $(1991,2005)$ the slightly larger mandible PIN-355-9 is identified as male, thus the conclusion that the canine of D. hypsilophus is smaller than that of D. ruscinensis. Actually, this mandible is from a female individual: $\mathrm{p} 3$ and $\mathrm{p} 4$ have a mesiobuccal flare but, as noted above, this is not rare in the females of D. ruscinensis and $\mathrm{p} 3$ is only slightly expanded below the level of the molar row, much less than in males of this species. The other mandible PIN-355-7 was correctly identified by Mashchenko as female: the alveolus for the canine is very small.

In conclusion we agree with Szalay \& Delson (1979) and Delson et al. (2005) that the Voynichevo-Grossulovo sample of D. "hypsilophus" is conspecific with the type-species of the genus. It may be somewhat smaller than the material from the type-locality, perhaps because it belongs to a population which is marginal both in time (latest MNQ 15 according to Mashchenko, 2005) and geography; the difference in size is not great but significant (Tables 1 and 3), and we prefer to keep the Kuchurgan specimens as a distinct sub-species, D. ruscinensis hypsilophus.

The comparison of the male specimen FM-1739 from Tenevo with the Kuchurgan females shows similar mandibular corpus depth but less corpus breadth and a much shorter canine and premolar row (Figs. 3-4); these differences are the opposite of those that could be 
expected from sexual dimorphism. The premolar and molar rows are straight, without the marked sigmoid curve of the Tenevo specimen. All these differences strongly suggest the existence of two different species.

Megalo Emvolon: Koufos et al. (1991) described left and right mandibular bodies of the same female individual from Megalo Emvolon as Dolichopithecus ruscinensis. The premolars are somewhat expanded below the level of the molars, a characteristic of several Perpignan females (see above); the small canine is typical for a female, and we agree with Koufos et al. (1991) as to the sex of the specimen. The dental and molar rows of the Greek mandible are slightly smaller than all known specimens of $D$. ruscinensis. More characteristic are: the lingually inclined $\mathrm{m} 3$ in respect to the other molars, the shallowness of the well-preserved left mandibular corpus and the shortness of c-p4, in part because of their arch-like disposition on the mandible and the strong overlap of p3 and c (Fig. 2, E-F). The Megalo Emvolon mandible shares with the Tenevo specimen all these features that separate the Greek and Bulgarian samples of Dolichopithecus from all other known samples. Metric differences between them (Figs. 3-4) are similar to those that occur between the sexes of modern P. badius, and we believe that they can be accommodated in the same species, Dolichopithecus balcanicus sp. nov., distinct from D. ruscinensis.

\section{General discussion}

In order to confirm the taxonomic distinctions suggested by the morphology, we have performed an ANOVA analysis on the mandibular measurements (Table 3). It shows that D. balcanicus differs statistically in all measurements from the sample of $D$. ruscinensis from Perpignan. Thus, the ANOVA analysis clearly supports the distinction between $D$. ruscinensis 
and D. balcanicus. The latter differs significantly from the largest Mesopithecus individuals only in molar row length and the alveolar premolar length. The Dolichopithecus from Kuchurgan does not significantly differ from $D$. balcanicus in any of the investigated measurements, but it must be noted that the Kuchurgan mandibles are all female, and that we may expect the measurements of the males to be more different from D. balcanicus. In contrast to D. balcanicus, the Ukrainian sample differs from the Perpignan sample in some measurements only. Its morphology is similar to that of the Perpignan sample, but it is smaller, and we accept it as a distinct sub-species.

Dolichopithecus is defined as a long-faced monkey (Szalay \& Delson, 1979) but the Balkan species might have had a shorter rostral part of the muzzle. As in D. ruscinensis the sexual dimorphism of the new species was weak as to molar and mandible length, but strong in c-p3 development.

The shortening of the premolar row compared to the molars could reflect a specialization to more tough and abrasive food, with an increase of the grinding function devoted to the molars and decrease of the cutting function of the premolars (the molars are relatively much longer than in the leaf-eating Piliocolobus). This adaptive change could be linked with the increasingly drier conditions at the end of the Ruscinian in south-eastern Europe. In the paleoprecipitation maps of Eronen and Rook (2004), there is a sharp increase, from zone MNQ 14 to zone MNQ 15, of the contrast between a wet Europe and a dry Eastern Mediterranean almost lacking primates. Dolichopithecus balcanicus, living at the border between the two regions, may represent an attempt to survive in an environment ill-suited for cercopithecids.

\section{Conclusions}


The Balkan specimens of Dolichopithecus from Tenevo and Megalo Emvolon represent a species distinct from D. ruscinensis - D. balcanicus sp. nov. It is characterized by small size, shallow and twisted mandibular corpus, and shortened premolar row. These morphological distinctions might have arisen from geographic (southeastern periphery of the D. ruscinensis range) and chronological differences from the typical population from Perpignan, and reflect changes in the environment to which D. ruscinensis was adapted. The Kuchurgan population from Grossulovo-Voynichevo can be regarded as a subspecies of $D$. ruscinensis reflecting also geographic and (to some extent) chronologic distance with the Perpignan population. The younger Asian finds from Shamar, Udunga and Nakatsu - if they really represent the genus Dolichopithecus - must be united in a separate subgenus, the valid name of which is D. (Parapresbytis) Kalmykov \& Mashchenko, 1992.

\section{Acknowledgements}

We are especially grateful to G.D. Koufos (LPGUT) who kindly allowed us to examine the Megalo Emvolon mandible, and to P. Tassy (MNHN), D. Berthet and M. Philippe (CCECL), A. Prieur (Université Claude Bernard, Lyon), and W. Wendelen (MRAC) for access to collections. Useful comments by E. Delson, W. Kimbel, H. Thomas, and two anonymous reviewers greatly improved the manuscript. E. Mashchenko (Institute of Paleontology, Moscow) kindly sent us casts of the Dolichopithecus remains from the Kuchurgan river valley and G. Ribarov collected and took care of the fossils from Tenevo. 


\section{References}

Alekseeva, L., 1964. New finds of bone remains of Cercopithecidae monkeys from the territories of the European part of USSR. Vopr. antropol. 16, 129-134.

Bonis, L. de, Bouvrain, G., Geraads, D., Koufos, G. 1990. New remains of Mesopithecus (Primates, Cercopithecoidea) from the Late Miocene of Macedonia (Greece), with the description of a new species. J. Vert. Pal. 10, 473-483.

Borissoglebskaya, M., 1981. A new species of monkey (mammalia, primates) from the Pliocene of northern Mongolia. In: Tatarinov, L., (ed.), ser.: Iskopaemye Pozvonochnie Mongolii (the fossil vertebrates of mongolia), Proceedings of the joint sovietmongolian research expedition, 15. Nauka, Moscow, pp. 95-108.

Delson, E., 1973. Fossil colobine monkeys of the circum-Mediterranean region and the evolutionary history of the Cercopithecidae (Primates, Mammalia). Ph.D. dissertation, Columbia University.

Delson, E., 1994. Evolutionary history of the colobinae monkeys in paleoenvironmental perspective. In: Davies, G., Oates, J., (Eds.). Colobine monkeys: their ecology, behaviour and evolution. Cambridge univ. press, pp. 11-43.

Delson, E., Brooks, A., Shea, J., 2000. Europe. In: Delson E., Tattersall, I., van Couvering, J., Brooks, A., (Eds.). Encyclopedia of Human Evolution and Prehistory, 2nd ed.. Garland, New York, pp. 239-254.

Delson, E., Thomas, H., Spassov, N., 2005. Fossil Old World monkeys (Primates:

Cercopithecidae) from the Pliocene of Dorkovo, Bulgaria. Géodiversitas. 27, 159-166.

Depéret, C., 1889. Sur le Dolichopithecus ruscinensis, nouveau singe fossile du Pliocène du Roussillon. C. R. Acad. Sci., Paris. 109, 982-983. 
Eronen, J. T., Rook, L., 2004. The Mio-Pliocene European primate fossil record: dynamics and habitat tracking. J. hum. Evol. 47, 323-341.

Fejfar, O., Heinrich, W.-D., Pevzner, M. A., Vangengeim, E. A., 1997. Late Cenozoic sequences of mammalian sites in Eurasia: an updated correlation. Palaeogeog., Palaeoclim., Palaeoecol. 133, 259-288

Gremjatsky, M., 1958. Fossil monkeys from the territory of the USSR in connection with some questions of phylogeny of the higher primates. Trudy VI vsesoyuznogo siezda anatomov, histologov i embriologov, 2, 576-579.

Iwamoto, M., Hasegawa, Y., Koizumi, A., 2005. A Pliocene colobine from the Nakatsu group, Kanagawa, Japan. Anthrop. sci. 113, 123-127.

Kalmykov, N. P., Mashchenko, E. N., 1992. The northernmost early Pliocene cercopithecidae from Asia. Paleontol. J. 26, 178-181.

Kojumdjieva, E., Stoykov, S., Markova, S., 1984. Lithostratigraphy of the Neogene sediments of the Tundja (Elhovo-Jambol) basin. Spisanie na bulgarskoto geolojko drujestvo 45, $287-295$

Koufos, G., Syrides, G., Koliadimou, K., 1991. A Pliocene primate from Macedonia (Greece). J. hum. Evol. 21, 283-294.

Koufos, G., Spassov, N., Kovatchev, D., 2003. Study of Mesopithecus (Primates, Cercopithecoidea) from the late Miocene of Bulgaria. Palaeontographica A. 269, 3991.

Mashchenko, E., 1991. The tooth system and the taxonomic status of the early Pliocene cercopithecid monkey Dolichopithecus hipsulophus (Primates, Cercopithecidae). 
Bulletin moskovskogo obshchestva ispitateley prirody, ser. geol. 66, 61-74 (in Russian).

Mashchenko, E., 2005. Cenozoic primates of eastern Eurasia (Russia and adjacent areas). Anthrop. sci. 113: 103-115.

Radulescu, C., 2005. Artiodactyles du Pliocène et du Pléistocène inférieur de Roumanie. In: Crégut-Bonnoure, E. (Ed.), Les ongulés holarctiques du Pliocène et du Pléistocène. Quaternaire. HS 2, 191-200.

Radulescu, C., Samson, P. E., Petculescu, A., Tiucã, E., 2003. Pliocene large Mammals of Romania. Coloq. paleontol. 53, 1-10.

Samson, P., Radulescu, C., Kisgyorgy, Z., 1971. Nouvelles données sur la faune de mammifères du Villafranchien inférieur de Capeni-Varghis. Eiszeitalt Ggw. 22, 64-88.

Stromer, E., 1913. Mitteilungen über die Wirbeltierreste aus dem Mittelpliocaen des Natrontales (Ägypten). Z. Dtsch. Geol. Ges. 65, 350-372.

Szalay, F., Delson, E. 1979. Evolutionary history of the primates. Academic press, New York, $580 \mathrm{p}$ 
Table 1. Mandibular measurements of Dolichopithecus and Mesopithecus. Measurements of Mesopithecus from Pikermi (PIK), Ravin des Zouaves (RZO), and Thessaloniki region (SLQ) are from Bonis et al., 1990. Those of Kuchurgan are from Mashchenko (1991), Gremjatsky (1958) and from casts. HD = Hadjidimovo (Koufos et al., 2003).

\begin{tabular}{|c|c|c|c|c|c|}
\hline No & $\begin{array}{c}\text { labial } \\
\text { depth of } \\
\text { mandible } \\
\text { below m2 }\end{array}$ & \begin{tabular}{|l|} 
mandible \\
thickness \\
below m2
\end{tabular} & \begin{tabular}{|c|} 
length from \\
distal border of \\
canine alveolus \\
to distal border \\
of p4 alveolus
\end{tabular} & Lm1-m3 & \begin{tabular}{|c|} 
oblique length \\
from most \\
posterior point of \\
symphysis to rear \\
of $\mathrm{m} 3$
\end{tabular} \\
\hline Dolichopithecus-Tenevo, male & $23 \max$. & 9.75 & 11.2 & 30.1 & $\sim 39.5$ \\
\hline \multicolumn{6}{|l|}{ Dolichopithecus - M. Emvolon: } \\
\hline MEV 1(sin.), female & 18.6 & 10.3 & $\sim 11.9$ & 30.5 & \\
\hline \multicolumn{6}{|l|}{ Dolichopithecus - Ukraine: } \\
\hline Kuchurgan 355-9, female & 22.9 & 10.3 & 15.8 & $\sim 30.5$ & $\sim 43$ \\
\hline Kuchurgan 355-7, female & 23.4 & 11.9 & $\sim 15$ & 31 & 45.5 \\
\hline Kuchurgan 355-8 & 26 & & & $\sim 30$ & \\
\hline \multicolumn{6}{|l|}{ Dolichopithecus - Perpignan: } \\
\hline FSL-40906, male & 32 & 12.4 & $\sim 17.6$ & 32.3 & 47.1 \\
\hline Per-003, male & $\sim 31.3$ & $\sim 11.3$ & 20 & 33 & 49.5 \\
\hline Pp-1, male & 31.5 & $\sim 11.2$ & $\sim 18.5$ & 37 & 52 \\
\hline Pp-2, male & 29.5 & & 13.7 & 32.5 & 45.2 \\
\hline Pp-9, male & & & & 32.5 & \\
\hline Pp-10, male & 33 & & $\sim 20$ & 33.5 & \\
\hline FSL-41288, female & & 13.5 & 22.5 & 33.5 & $48+$ \\
\hline Pp-3, female & 28 & & 16.5 & 32.5 & 45.5 \\
\hline Per-004, female (cast) & & 12.9 & $\sim 18$ & 34.9 & 49 \\
\hline \multicolumn{6}{|l|}{ Mesopithecus } \\
\hline Mesopithecus HD 392, male & 20.3 & 9.1 & 6.2 & & 32.3 \\
\hline Mesopithecus HD 340, male & 23.1 & & & 26.7 & 38.4 \\
\hline Mesopithecus HD 339, male & 24.9 & 9.5 & 7.0 & & $\sim 37.5$ \\
\hline Mesopithecus $\mathrm{PIK}$, males $(\mathrm{N}=11)$ & 19.7 & & & 23.4 & \\
\hline Mesopithecus SLQ 940 & 22.7 & & & & \\
\hline Mesopithecus $\mathrm{RZO}$, males $(\mathrm{N}=2)$ & 25.2 & & & 25.1 & \\
\hline
\end{tabular}


Table 2. Dental measurements of Dolichopithecus. Megalo Emvolon from Koufos et al., 1991; Perpignan from Delson, 1973.

\begin{tabular}{|c|c|c|c|c|c|c|c|}
\hline & $\mathrm{m} 1$ length & $\begin{array}{c}\text { m1, width } \\
\text { of } 2^{\text {nd }} \\
\text { lophid }\end{array}$ & $\mathrm{m} 2$ length & $\begin{array}{c}\text { m2, width } \\
\text { of } 1^{\text {st }} \\
\text { lophid }\end{array}$ & $\begin{array}{l}\mathrm{m} 2 \text {, width } \\
\text { of } 2^{\text {nd }} \text { lophid }\end{array}$ & m3 length & $\begin{array}{l}\text { length m1- } \\
\text { m3 }\end{array}$ \\
\hline \multicolumn{8}{|l|}{ D. balcanicus } \\
\hline Tenevo & 8.7 & 7.3 & 9.8 & 7.9 & 8.0 & 11.8 & 30.1 \\
\hline Megalo Emvolon & 9.4 & 7.1 & 10.2 & 7.6 & 7.8 & 11.4 & 30.5 \\
\hline \multicolumn{8}{|l|}{ D. ruscinensis } \\
\hline Perpignan & $\begin{array}{c}9.31 \\
(8.8-9.9)\end{array}$ & $\begin{array}{c}6.83 \\
(6-7.7)\end{array}$ & $\begin{array}{c}10.5 \\
(9.5-12.1)\end{array}$ & $\begin{array}{c}8.03 \\
(7-9.3)\end{array}$ & $\begin{array}{c}8.1 \\
(7.1-9)\end{array}$ & $\begin{array}{c}13.16 \\
(11.9-14.7)\end{array}$ & $30.8-33.5$ \\
\hline
\end{tabular}


Table 3. Results of the ANOVA analysis. In each column, values marked with a different letter are significantly different at $\mathrm{P} \leq 0.05$ by ANOVA followed by Least Significant Difference test (STATISTICA 4.3 for Windows (StatSoft, Inc. 1993))

\begin{tabular}{|c|c|c|c|c|c|}
\hline Species & $\begin{array}{c}\text { labial depth of } \\
\text { mandible below } \\
\mathrm{m} 2\end{array}$ & $\begin{array}{c}\text { mandible } \\
\text { thickness below } \\
\mathrm{m} 2\end{array}$ & $\begin{array}{c}\text { length from } \\
\text { distal border of } \\
\text { canine alveolus } \\
\text { to distal border } \\
\text { of } \mathrm{p} 4 \text { alveolus }\end{array}$ & Lm1-m3 & $\begin{array}{c}\text { oblique length } \\
\text { from rear of } \\
\text { symphysis to } \\
\text { rear of m3 }\end{array}$ \\
\hline $\begin{array}{c}\text { Dolichopithecus } \\
\text { balcanicus }\end{array}$ & $\begin{array}{c}20.80 \pm 2.20 \\
\mathrm{~b}\end{array}$ & $\begin{array}{c}10.03 \pm 0.28 \\
\mathrm{~b}\end{array}$ & $\begin{array}{c}11.55 \pm 0.35 \\
\mathrm{~b}\end{array}$ & $\begin{array}{c}30.30 \pm 0.20 \\
\mathrm{~b}\end{array}$ & $\begin{array}{c}39.5 \\
\mathrm{bc}\end{array}$ \\
\hline $\begin{array}{c}\text { Dolichopithecus } \\
\text { Ukraine }\end{array}$ & $\begin{array}{c}23.67 \pm 1.20 \\
\mathrm{~b}\end{array}$ & $\begin{array}{c}11.10 \pm 0.80 \\
\mathrm{ab}\end{array}$ & $\begin{array}{c}15.40 \pm 0.40 \\
\mathrm{ab}\end{array}$ & $\begin{array}{c}30.50 \pm 0.29 \\
\mathrm{~b}\end{array}$ & $\begin{array}{c}44.25 \pm 1.25 \\
\mathrm{ab}\end{array}$ \\
\hline $\begin{array}{c}\text { Dolichopithecus } \\
\text { Perpignan }\end{array}$ & $\begin{array}{c}30.46 \pm 0.68 \\
\mathrm{a}\end{array}$ & $\begin{array}{c}12.26 \pm 0.45 \\
\mathrm{a}\end{array}$ & $\begin{array}{c}18.35 \pm 0.93 \\
\mathrm{a}\end{array}$ & $\begin{array}{c}33.52 \pm 0.51 \\
\mathrm{a}\end{array}$ & $\begin{array}{c}48.04 \pm 0.90 \\
\mathrm{a}\end{array}$ \\
\hline Mesopithecus & $\begin{array}{c}22.65 \pm 0.93 \\
\mathrm{~b}\end{array}$ & $\begin{array}{c}9.30 \pm 0.20 \\
\mathrm{~b}\end{array}$ & $\begin{array}{c}6.60 \pm 0.40 \\
\mathrm{c}\end{array}$ & $\begin{array}{c}25.07 \pm 0.95 \\
\mathrm{c}\end{array}$ & $\begin{array}{c}36.07 \pm 1.90 \\
\mathrm{c}\end{array}$ \\
\hline
\end{tabular}




\section{Captions to figures}

Figure 1. Map of Bulgaria and surrounding areas with the location of: 1: Megalo Emvolon; 2: Tenevo; 3: Kuchurgan River valley.

Figure 2. Dolichopithecus balcanicus. A-D: holotype, Tenevo. A: antero-dorso-lateral view (stereo); B: occlusal view (stereo); C: lingual view; D: labial view. E-F: referred specimen, Megalo Emvolon. E: occlusal view (stereo reversed from the left side, for comparison with A-B); F: labial view. Scale $=2 \mathrm{~cm}$.

Figure 3. Plot of m1-m3 length vs. premolar alveolar length, from distal border of canine alveolus to distal border of $\mathrm{p} 4$ alveolus, in Dolichopithecus and Piliocolobus.

Figure 4. Plot of canine and premolar length, from mesial edge of the canine to distal border of p4 alveolus, vs. mandible depth at m2, in Dolichopithecus and Piliocolobus.

Measurement of c-p4 of the Tenevo specimen is a maximum estimate, as it is based upon a canine of $D$. ruscinensis from Dorkovo. 